\title{
Investigating the Relationship among the Level of Mobbing Experience, Job Satisfaction and Burnout Levels of Primary and Secondary School Teachers ${ }^{i}$
}

\author{
Veysel Okçu*, Hakan Çetin \\ Faculty of Education, Siirt University, Turkey
}

Copyright $(2017$ by authors, all rights reserved. Authors agree that this article remains permanently open access under the terms of the Creative Commons Attribution License 4.0 International License

\begin{abstract}
The aim of this study is to examine the level of mobbing experienced by primary and secondary school teachers and to determine how and to what extent this affects their job satisfaction and burnout levels. This research used a relational survey model. As a result of the study, it has been determined that there is a negative and medium-level relationship between the teachers' level of exposure to mobbing towards their profession or social relationships and their job satisfaction levels; a positive and medium-level relationship between the teachers' level of exposure to mobbing towards their profession or social relationships and their burnout levels; and a negative and low-level relationship between their internal and external job satisfaction levels and their burnout perceptions. According to the results of the path analysis, the teachers' job satisfaction level decrease in line with an increase in their mobbing experiences related to their profession and social relationships, and thus, their burnout levels also increase. However, it has also been determined in the study that in line with an increase in the internal and external job satisfaction levels of teachers, their burnout perceptions decrease. Accordingly, it has been concluded that mobbing towards their profession and social relationships is a stronger predictor of burnout level in comparison to job satisfaction.
\end{abstract}

Keywords Mobbing, Job Satisfaction, Burnout, Teacher, Primary and Secondary School

\section{Introduction}

In an organisational environment, many different variables may have an effect on the job dissatisfaction and burnout of workers. One of these variables is mobbing. Mobbing is a concept that triggers stress, enhances its scope and renders it more serious [1]. Mobbing is systematically exposing one or (rarely) several employees to emotionally deleterious behaviours in the workplace by one or more employees (rarely more than four) each day or for some months [2]. The studies carried out by Işık [3] and Tayyar [4] showed that there is a significant relationship between mobbing practices and job stress level and job performance. Mobbing behaviour at work, which occurs as a result of the accumulation of psychological factors leading to tension and conflicts in the organisation, is one of the main problems that distorts organisational order, decreases performance, harms motivation, impairs commitment to work and has a negative effect on job satisfaction and working environment [5],[6],[7]. Besides its negative effect on workers, mobbing negatively effects the organisations and causes loss of time and energy [8].

Burnout is a main factor affecting the job stress levels of employees; this and the accompanying loss of productivity are among the unfavourable conditions commonly in many social organisations. Burnout means an individual becoming insensitive to other people they meet as a result of their work, feeling exhausted and feeling less successful [9]. Burnout has a negative effect on occupational performance. Even if the individual does not leave their job, it reflects the unfavourable experiences of their work. Rapid change of expectations concerning the organisation and the environment, and the individual's inability to keep up with this rapid change, enhances the feeling of burnout. Crowded places, limited opportunities, administrative pressure, low motivation of the administrators, unfavourable working conditions and personal and family matters are among the prominent reasons for burnout among workers [10]. It is considered that emotional stress factors observed, especially in jobs necessitating face-to-face contact with people, are related to burn out, as different from other factors [11].

Another main factor affecting the job stress levels of the employees is burnout. According to Izgar, when the employees achieve their expectations in their working life, they feel more positive and this helps them develop a positive attitude towards their work [12]. Job satisfaction corresponds to the attitude of an individual towards his work 
and covers his knowledge, beliefs, feelings, behaviours and considerations [13]. Job satisfaction is a pleasurable or positive emotional state resulting from the appraisal of one's job or job experiences [14]. Studies examining the relationship between the job satisfaction levels of workers and their psychological and physical health indicate that those with higher job satisfaction levels are healthier and have less stress in comparison with other employees [15]. Moreover, high job satisfaction levels affect psychological and physical health and enhance the self-confidence of an employee [16]. From a different perspective, job dissatisfaction leads to anxiety, depression, abstention, disciplinary problems and high employee turnover rates [17].

Research carried out in Turkey especially during 1980s on the job satisfaction [16], [18], [19], [20], [21], [22], [23], [24] and as of the mid-1990s on burnout [25], [26], [27], [28], [29], [30], [31] and on the job stress levels of teachers [3], [23], [32], [33], [34], [35] showed that the job satisfaction levels of teachers are low while their burnout levels are high that the teaching profession is more stressful in comparison with the other professions and that teachers face stress intensely in their working environments. Research carried out in other countries [1], [36], [37], [38], [39], [40], [41], [42], [43], [44], [45], [46] revealed that individuals who are exposed to mobbing have lower levels of job satisfaction, higher levels of burnout, bear indications of mental fatigue, have an increasing rate of psychological health problems, have higher levels of depression and anxiety, display more aggressive behaviours and experience serious health impairments. Korkmaz and Cemaloğlu pointed that in educational institutions with intense social relationships, mobbing weakens organisational trust and climate [47]; and Zapf argued that mobbing impairs organisational climate, leads to job stress and therefore increases accompanying problems [46]. Moreover, Araujo et al. and Toker Gökçe determined that the mobbing at work, organisational climate and psychological and physical health of workers are related, while Jenkins et al. determined that mobbing at work and job performance of the workers, their motivation and organisational trust are related [37], [42], [48]. Kocaoğlu reported that mobbing has a negative effect on the motivation of the people exposed to it [6]. Sürgevil stated that there is a negative relationship between job satisfaction and burnout [49]. Some researchers consider that job satisfaction decreases as a result of burnout. Although both concepts point to internal, negative and psychological experiences, burnout differs from job satisfaction by corresponding to a decrease in energy for work. Moreover, burnout is distinguished from job satisfaction as it is stated to mean psychological tension caused by occupational stress [50].

Matters such as the differentiation of social roles, conflicts experienced in relationships among workers, existence of competition in an organisational environment, self-actualisation efforts of the workers, high expectations negatively affecting the psychological health of workers, cause stress. In this regard, this study aims at examining the level of exposure to mobbing among the primary and secondary school teachers, and how and to what extent this affects their job satisfaction and burnout levels. By penetrating into the living spaces of organizations, making a close analysis of mobbing which has a negative effect on quality and success and examining the variables that may be related with mobbing may facilitate the understanding of the problem. It is important that teachers are aware of mobbing, an obstacle to a favourable working environment and of its harmful effects. This research aims to highlight this harmful effect and to ensure a favourable organisational climate for teachers, to increase the learning success of the students by these means, and therefore, to make a contribution to the quality of education.

\subsection{Conceptual Framework}

\subsubsection{Mobbing}

According to Leymann, mobbing is psychological terror by one or several people towards another person or other people, by systematic hostile and unethical practices [1]. Mobbing is a kind of systematic and long-term behaviour that directly targets an employee and may cause psychological and physiological damage [51] and is any kind of behaviour towards an employee such as maltreatment, threatening, violence and humiliation displayed by senior staff, subordinates or colleagues of an equal rank [52]. As understood from the above-mentioned definitions, mobbing is a concept that exists since the beginning of the history of working life; however, there is no commonly accepted understanding about its definition. Moreover, some people who are exposed to mobbing at work consider this a routine conflict in the workplace and an everyday problem. This misleads the research and renders it difficult to make a diagnosis [53].

\subsubsection{Work-related Mobbing}

Branch defines work-related mobbing as hiding important information from the employee, continuously monitoring their work and gossiping about them [54]. Mobbing may be seen in various ways, for example implying that the employee is a liar, teasing them, gossiping about them or hindering their communication with other people, subjecting them to a heavy workload, alienating them, subjecting them to verbal threats and supervising them often and unnecessarily [8]. According to Einarsen and Raknes, work-related mobbing covers the prevention of teachers to obtain information that may affect their success, humiliation by employing them below their competences, assignment of tasks below their abilities, gossiping about them and ignoring, excluding and disregarding them [40]. Leymann (1993) lists some of the work-related mobbing behaviours as [1], [53], [55], [56], [57]: (1) not assigning the important tasks, (2) limitation of tasks, (3) asking for meaningless tasks, (4) assigning tasks below competences, (5) continuously assigning new tasks, (6) assigning tasks that impair 
self-esteem, (7) assigning tasks not complying with his nature, (8) forcing them to undertake a difficult task, (9) make them pay for losses.

\subsubsection{Mobbing Directed at Social Relations}

Receiving attention in a group, having a place there and feeling important to the group, are among the most basic needs of an individual. Social relationships are an important means of communication that makes existence meaningful [6], [58]. Mobbing may sometimes be directed at hindering the social relationships that are among the basic needs of an employee [58]. According to Einarsen and Raknes, mobbing directed at social relationships covers using offensive terms and behaviours about someone's personality, attitude and private life, unpleasant jokes, excessive teasing and ridiculing, shouting at them and displaying momentary anger, pointing at them and bullying behaviours such as attacking someone's personal sphere, pushing or intercepting them [40]. Leymann (1993) summarises mobbing related to social relationships as follows [1], [53], [55], [56], [57]: (1) no-one talks with the employee and they are excluded from the group, (2) they are not allowed to speak with other employees and are deprived of the right to meet with other people, (3) they are left isolated and alone (4), other people are prohibited to talk with them, (5) they are ignored. These behaviours will not only affect those who are exposed to mobbing but also employees witnessing the process and cause them to lose their trust in the organisation.

\subsubsection{Burnout}

The concept of burnout was first defined in 1974 by Freudenberger, and in the last 20 years much research has been carried out in various fields of work. Freudenberger defined burnout as being unsuccessful, fraying, decreasing in energy and power and a state of exhaustion in the internal resources of a person, as a result of unsatisfied desires [59], [60], [61], [62], [63], [64], [65], [66], [67], [68], [69], [70], [71], [72]. Today, the most widely recognised definition of burnout is the three-dimensional definition developed by Maslach and Jackson and it pioneers the studies in this field [9]. According to Maslach and Jackson, burnout means 'emotional exhaustion, depersonalisation towards other people at work and reduced feeling of personal accomplishment.' Burnout that teachers or schools administrators face is addressed in three dimensions as emotional exhaustion, depersonalisation and personal accomplishment [9], [62]. Depersonalisation points to the interpersonal dimension of burnout [60] and is observed as attitudes and behaviours devoid of feelings displayed by an individual towards the people they serve, ignoring them as an individual. The person displays an inhumane, teasing, humiliating, strict, stony and indifferent attitude [11], [73]. Emotional exhaustion is defined as a state of burnout caused by excessively burdening the employee with work [74]. It is stated that burnout starts with emotional exhaustion and the other dimensions are felt later on and that emotional exhaustion is the most important determinant of burnout [29].
Emotional exhaustion is the feeling of burnout due to excessive work load. The individual feels emotionally exhausted and thinks that they cannot fulfil their responsibilities towards the institution [69]. Feeling that their emotional resources are exhausted, the individual begins to think that they are not as productive and responsible as before, and when they are not able to overcome this state, they may not want to go to work, may be late, may be absent or may resign [75]. After reduced personal accomplishments, the individual with negative thoughts about other people begins to think negatively also about themselves [76], [77]. The individual whose personal accomplishments have reduced feels that they cannot progress and even are regressing in their profession [78] and begins to feel guilty. This may cause the individual to value themselves negatively, to believe that they are not effective in the organisation, to lose self-respect and to sink into depression [11].

\subsubsection{Job Satisfaction}

Since the 1940s, job satisfaction has been among the most commonly discussed topics in the field of management. According to Balc1 (1985), job satisfaction means the feelings aroused in an individual in relationship to whether their requirements, expectations and desires concerning the different dimensions of work are satisfied. Job satisfaction as a phenomena is an emotional reply caused by the interaction of values related to work and acquisitions from work [79], [80], [81], [82]. Job satisfaction, one of the most effective means of increasing the productivity of a worker in the working environment, reflects the attitude of the employer towards the work; when this attitude is positive, the level of job satisfaction is also high and vice versa. However, in order to increase productivity in this sense, organisations should consider all psychological, economic and social expectations of the employee. Adaptation to work and the rules of the organisation will improve job satisfaction and productivity [83]. Keeping the communication channels open between the administrators and workers and providing the opportunity to the workers to express themselves are important for the enhancement of job satisfaction. If the worker participates effectively in the decision-making process, they begin to embrace work more and feel more satisfied [84].

Job dissatisfaction is depressing for the worker and may cause them to have negative feelings. When job dissatisfaction leads to anxiety that is intense and permanent, the psychological health of the worker may be effected negatively and result in unfavourable behaviours within the organisation, such as weariness, leaving the job, absenteeism and quarrelsomeness [82]. In his study, Balc1 determined that school administrators feel job dissatisfaction, although not at high levels [16]. There are many factors affecting the job satisfaction of the worker. Individual factors or personal factors are elements leading to different job satisfaction levels [85]. Internal factors represent themselves and the need for them emerges automatically. These factors are 
related with meeting superior needs such as personal requirements and reputation [23]. Organisational (external) factors are grouped into the nature of the work, management style, supervision type, feeling of security, communication, opportunities of income, improvement and promotion, competition, colleagues and organisational environment [85]. External factors include management, technical matters, colleagues, as well as requirements concerning payments, promotion and advancement, and guarantees [23].

\subsubsection{The Relationship among the Variables of Mobbing, Job Satisfaction and Burnout}

Existence of mobbing attack at work may be related with organisational culture. If policies to observe, prevent or punish mobbing attacks are not established in an organisation, the attackers have the opportunity to apply mobbing and accordingly the organisation will have to bear the consequences [86]. Research regarding the effects of mobbing at work on job satisfaction [39], [87], [88] indicated a negative relationship between mobbing and job satisfaction and showed that the psychological health of those who are subjected to mobbing is affected by decreasing job satisfaction. In the study carried out by Çivilidağ among university academics, it was found out that there is a negative relationship between the mobbing experiences of academics at work and their job satisfaction and perceived social support levels [89]. Moreover, in Doğan's study on the relationship between mobbing behaviours and job satisfaction, a negative and medium-level relationship was determined between these two variables [90].A study carried out by Okan among secondary school teachers revealed no significant relationship between the mobbing experience of teachers and their job satisfaction levels [91]. However, Dinçer's study pointed that the level of exposure to violence is rather high among nurses, mobbing behaviours affect their job satisfaction levels and thus, they think of leaving the job [92].

Burnout is an important result of violence at work. Burnout, which is simply defines as the 'exhaustion of psychological and physical energy' [60], not only affects the working life of the individual but also their whole life [93]. Alkan's study revealed a positive relationship between the mobbing behaviours and the burnout levels of teachers [94]. Karakuş and Çankaya stated that stress and burnout levels of teachers also increase in line with an increase in the mobbing experience [95]. Alkan reported that there is a significant and positive relationship between the mobbing and only the 'emotional exhaustion' sub-dimension of burnout while there is not a significant relationship between the 'personal accomplishment' and 'depersonalisation' sub-dimensions [94]. Similarly, the study of Filizöz and Ay revealed a positive relationship between mobbing and the emotional exhaustion and depersonalisation sub-dimensions of burnout and indicated that there is not a significant relationship between mobbing and personal accomplishment [96]. In Bucaklar's study carried out among teachers, it was found out that there is a positive relationship between mobbing and burnout [97]. A positive relationship was determined between mobbing and burnout in the study by Varhama and Björkqvist in Finland among municipality workers and that by Einarsen, Matthiesen and Skogstad in the health sector in Norway [98]. Koustelios and Tsigilis found that there is a negative and significant relationship between internal job satisfaction and burnout [99]. The study carried out by Gençer among teachers and that carried out by Bayram, Gürsakal and Bilgel among academics found a negative and significant relationship between the job satisfaction levels of workers and their burnout levels [100], [101].

Feeling of satisfaction in the organisation by employees is mostly possible through an inherent communication among them. This satisfaction affects the commitment of the employee and thus, the level of commitment plays an important role for the maintenance of the organisation [102]. Considering the effect of mobbing at schools, which increases the stress and burnout levels of teachers and decreases organisational commitment, job and life satisfaction, and the trust in the administration and the organisation [90], [95], [103], [104], [105] the question of which behaviours cause mobbing at which level becomes important. Therefore, determining the mobbing behaviours at schools and trying to lessen the accompanying negative effects on the employees and the organisation constitute the first step of the fight against mobbing. This research aims at examining the level of exposure to mobbing among primary and secondary school teachers, and how and to what extent this affects their job satisfaction and burnout levels.

\subsubsection{Purpose of the Study}

This research was carried out to examine the level of exposure to mobbing among primary and secondary school teachers, and how and to what extent this affects their job satisfaction and burnout levels. To this end, the following questions were posed:

1) What is the level of exposure to mobbing (in the dimensions of work-related mobbing and mobbing directed at social relationships) among primary and secondary school teachers?

2) What is the level of job satisfaction (in the sub-dimensions of internal satisfaction and external satisfaction) among primary and secondary school teachers?

3) What is the level of burnout (in the sub-dimensions of depersonalisation, emotional exhaustion and personal accomplishment) among primary and secondary school teachers?

4) Is there a significant relationship between the level of exposure to mobbing among primary and secondary school teachers and their job satisfaction and burnout levels?

5) How and to what extent does the exposure to mobbing among primary and secondary school teachers affect their job satisfaction and burnout levels? 


\section{Method}

\subsection{Research Model}

This research used the relational survey model, a research model for detect the existence and/or level of covariance between two or more variables [106]. In this research model, there are three variables, two independent and one dependent. Work-related mobbing is a part of the independent variables of the research model. Another independent variable is the mobbing directed at social relationships. However, as job satisfaction has a direct and indirect effect on burnout, it was addressed as both independent and dependent variable. During the path analysis in the research, sub-dimensions of mobbing were not measured separately; and the processed data were addressed as two separate mobbing types, 'work-related mobbing' and 'mobbing directed at social relationships'. Other independent variables of the research are internal and external satisfaction, which are the sub-dimensions of the job satisfaction of teachers. Dependent variables of the research are the depersonalisation, emotional exhaustion and personal accomplishments that are the sub-dimensions of burnout. Accordingly, how the level of exposure to work-related mobbing and mobbing directed at social relationships among primary and secondary school teachers affect their perceived job satisfaction and burnout levels is examined in the proposed model. It is presumed in the study that the perception of teachers regarding their experience of work-related mobbing and mobbing directed at social relationships affect job satisfaction directly and burnout levels both directly and indirectly through job satisfaction.

\subsection{Population and Sample}

The research population of this study comprised 1946 teachers in total, working in 48 primary school $(1058$ primary school teachers) and 44 secondary ( 888 branch teachers) schools in the central district of Siirt and in its district centres during the 2014-2015 academic year. In order to obtain more reliable research data and as the number of teachers included in the research population is not high, sampling was not made. The data of 1116 teachers who did not fill in the forms or who filled the form in deficiently were excluded from the evaluation. The data of 830 teachers were found eligible for analysis. Thus, nearly $43 \%$ of the target population provided usable data for analysis. $36.1 \%$ of the teachers who participated in the research were female and $63.9 \%$ were male. When the distribution by the seniority variable is examined, it is seen that the percentage of teachers in the seniority group $1-5$ years $(47.6 \%)$ and $(33.6 \%)$ years is higher than other groups, while the percentage of teachers in the 16-20 years (7.9\%) and 21 years or above is lower than other groups. The percentage of class teachers who participated in the research was $53.2 \%$ and that of branch teachers was $46.8 \%$.

\subsubsection{Negative Acts Questionnaire}

In order to determine the frequency of exposure by the teachers to negative acts addressed under the scope of the mobbing dimensions as work-related mobbing and mobbing directed at social relations, the Negative Acts Questionnaire Scale (NAQS) developed by Einarsen and Raknes was utilised [40]. NAQS is a five-point Likert scale answered and graded as daily (5), weekly (4), monthly (3), now and then (2), never (1). In the validity and reliability study, two factors were determined in the NAQS. Total variance explained by the first factor, work-related mobbing, was $39.40 \%$ and the eigenvalue of this factor was 9.03 . Variance explained by the second factor, mobbing directed at social relationships was $12.41 \%$ and the eigenvalue of this factor was 4.63 . Total variance explained by both dimensions was $51.81 \%$. The first factor was related to mobbing directed at social relationships and composed of 15 items. Factor loads varied between .45 and .80. The second factor concerns work-related mobbing. In this dimension, six items were included. The factor loads of the items under work-related mobbing varied between .47 and .74 . In order to determine the reliability of the NAQS, the Cronbach Alpha coefficient was utilised. The Cronbach Alpha coefficient of internal consistency was measured both for the whole scale and for each sub-dimension separately and specified as criteria of reliability. Internal reliability coefficient of these two sub-dimensions was .89 in the dimension of mobbing directed at social relationships and .76 in the dimension of work-related mobbing. In all dimensions of the scale, item-test correlations of 21 items varied between .49 and .80 .

\subsubsection{Maslach Burnout Scale and Reliability Study}

The Maslach Burnout Scale developed by Maslach and Jackson [9], which is used widely to determine the burnout levels of teachers, is composed of 22 items and addresses burnout in three sub-dimensions. In the Maslach Burnout Inventory (MBI), items under the sub-dimensions of emotional burnout and depersonalisation were scored alike while the items under personal accomplishment were subjected to adverse scoring and the total score was obtained [59]. A high score obtained in the sub-dimensions of emotional exhaustion and depersonalisation and a low score obtained in the personal accomplishment scale point to burnout. Medium-level scores in all three scales correspond to medium levels of burnout. Validity and reliability coefficients of MBI in teachers were determined by Maslach and Jackson. The reliability coefficient of the scale was .88 for emotional exhaustion, .83 for personal accomplishment and .72 for the depersonalisation sub-dimension. Girgin and Baysal [107] tried to adapt the scale for Turkey. Girgin determined the reliability coefficient as .87 for emotional exhaustion, .74 for personal accomplishment and .63 for depersonalisation. However, Baysal determined it as .74 for emotional exhaustion, .77 for personal accomplishment 
and .75 for depersonalisation [107]. Under this research, in the validity and reliability study of the MBI, it was determined that the scale has a three-factor structure. Total variance explained by the first factor, emotional exhaustion, was $24.30 \%$ and the eigenvalue of this factor was 8.07 . Variance explained by the second factor, the depersonalisation dimension of burnout, was $13.91 \%$ and the eigenvalue of this factor was 5.93. Variance explained by the third factor, the personal accomplishment dimension of burnout, was $8.02 \%$ and the eigenvalue of this factor was 4.24. Total variance explained by three dimensions was $46.23 \%$. The first factor was related to emotional exhaustion and composed of nine items. Factor loads varied between .49 and .83 . The second factor concerns the depersonalisation dimension. In this dimension, five items were included. Factor loads in the depersonalisation dimension varied between .52 and .79 . The third factor refers to personal accomplishment and includes eight items. Factor loads in the personal accomplishment dimension varied between .55 and .84. In the research, the Cronbach Alpha reliability coefficient of the MBI was determined as .89 for emotional exhaustion, .68 for the depersonalisation sub-dimension and .77 for the personal accomplishment sub-dimension.

\subsubsection{Minnesota Job Satisfaction Scale Short Form}

In order to determine the job satisfaction levels of teachers, the Turkish version of the Minnesota Job Satisfaction Scale developed by Weiss, Davis, England and Lofquist [108] was utilised. The scale was translated into Turkish by Baycan [109]. The Minnesota Job Satisfaction Scale comprised 100 questions but in this research the short form of the scale, which covers 20 items, was utilised and each item was scored in a five-point Likert scale $(1=$ very dissatisfied, $2=$ dissatisfied, $3=$ undecided, $4=$ satisfied, $5=$ very satisfied). The Minnesota Job Satisfaction Scale has two sub-dimensions, internal and external. Internal job satisfaction was measured through 11 items while external job satisfaction through items. Numerical values of the five-point Likert scale under job satisfaction scale are as follows: Very dissatisfied, 1.00-1.79; Dissatisfied, 1.80-2.59; Somewhat satisfied, 2.60-3.39; Satisfied, 3.40-4.19; and Very satisfied, 4.20-5.00. In the validity and reliability study, two factors were noted for job satisfaction. Total variance explained by the first factor, internal job satisfaction dimension, was $34.40 \%$ and the eigenvalue of this factor was 14.023 . Variance explained by the second factor, external dimension of job satisfaction, was $16.81 \%$ and the eigenvalue of this factor was 6.83 . Total variance explained by both dimensions was $51.21 \%$. The first factor was composed of 11 items and the factor loads varied between .54 and .85 . The second factor was composed of nine items and the factor loads varied between .49 and .78. In order to determine the reliability of job satisfaction scale, the Cronbach Alpha coefficient was measured. Internal reliability coefficients of these two sub-dimensions were .91 for internal job satisfaction and .78 for external job satisfaction. The reliability coefficient of the whole scale was .87. In all dimensions of the scale, item-test correlations of 20 items in the sub-dimensions of the scale varied between .49 and .85 .

\subsection{Data Collection and Analysis}

Scales were applied to 1946 teachers in total, working in 48 primary schools in the central district of Siirt and in its district centres. After the application, forms that were not filled or filled deficiently were sorted out and the data in the remaining 830 forms were evaluated. AMOS 22 and SPSS 21 statistical package programmes were used for data analysis. Descriptive statistics of the variables were produced using SPSS 21 while AMOS 22 was used to test the research models. The research hypotheses were tested at .01 and .05 significance levels.

\section{Results}

\subsection{Findings Regarding the Exposure of Teachers to Mobbing Behaviours and Their Job Satisfaction and Burnout Levels}

Table 1 displays the descriptive statistics concerning the mobbing experience of primary and secondary school teachers who participated in the research, and their job satisfaction and burnout levels.

As seen in Table 1, the average of the scores given by the primary and secondary school teachers, which was $\bar{x}=1.56, \mathrm{~S}=78$ for the work-related mobbing and $\bar{x}=1.37, \mathrm{~S}=53$ for the mobbing directed at social relationships reveal that the teachers experience mobbing 'now and then'. It may be stated that the internal job satisfaction levels of primary and secondary school teachers are good $(\bar{x}=3.54, \mathrm{~S}=.74)$ while their external job satisfaction levels are at a medium level $(\bar{x}=3.12, \mathrm{~S}=.65)$. Considering the distribution by burnout levels of the primary and secondary school teachers, in Table 1 the highest score is observed in emotional exhaustion ( $\bar{x}=3.07, \mathrm{~S}=.81$ ), while the lowest is seen in the depersonalisation $(\bar{x}=2.08, \mathrm{~S}=.59)$ sub-dimension. It was determined that the personal accomplishments of the teachers are at a medium level. In other words, these may be construed as teachers have exhausted their internal resources, have difficulty in getting into contact with other people and considering themselves as incompetent of a good performance.

\subsection{Findings Regarding the Correlations between the Sub-dimensions of Mobbing, Job Satisfaction and Burnout}

Table 2 displays the correlational relationships between the mobbing, job satisfaction and burnout variables. 
Table 1. Descriptive statistics concerning the mobbing experience, and the job satisfaction and burnout levels of the teachers, on the basis of the perceptions of primary and secondary school teachers

\begin{tabular}{cccc}
\hline Variables & $\mathrm{N}$ & $\bar{x}$ & $\mathrm{~S}$ \\
\hline Sub-dimensions of mobbing & & & \\
\hline Work-related mobbing & 830 & 1.56 & .78 \\
\hline Mobbing directed at Social relationships & 830 & 1.37 & .53 \\
\hline Sub-dimensions of job satisfaction & & & \\
\hline Internal satisfaction & 830 & 3.54 & .74 \\
\hline External satisfaction & 830 & 3.12 & .65 \\
\hline Sub-dimensions of burnout & & & \\
Emotional exhaustion & 830 & 3.07 & .81 \\
Depersonalisation & 830 & 2.08 & .59 \\
Personal accomplishment & 830 & 3.21 & .71 \\
\hline
\end{tabular}

Table 2. Correlational relationships between the mobbing, job satisfaction and burnout variables

\begin{tabular}{|c|c|c|c|c|c|c|}
\hline Variables & 1 & 2 & 3 & 4 & 5 & 6 \\
\hline \multicolumn{7}{|l|}{$\begin{array}{l}\text { Sub-dimensions of mobbing } \\
\text { 1. Work-related mobbing }\end{array}$} \\
\hline 2. Mobbing directed at social relationships & $.81^{* *}$ & & & & & \\
\hline \multicolumn{7}{|l|}{ Sub-dimensions of job satisfaction } \\
\hline 3. Internal satisfaction & $-.39^{* *}$ & $-.35^{* *}$ & & & & \\
\hline 4. External satisfaction & $-.31^{* *}$ & $-.30^{* *}$ & $.66^{* *}$ & & & \\
\hline \multicolumn{7}{|l|}{ Sub-dimensions of burnout } \\
\hline 5. Emotional exhaustion & $.52^{* *}$ & $.34^{* *}$ & $-.22 * *$ & $-.21^{* *}$ & & \\
\hline 6. Depersonalisation & $.41^{* *}$ & $.43^{* *}$ & $-.24 * *$ & $-.15^{* *}$ & $.65^{* *}$ & \\
\hline 7. Personal accomplishment & -.17 & -.15 & $.24 * *$ & $.03 * *$ & $-.19 * *$ & $-.23 * *$ \\
\hline
\end{tabular}

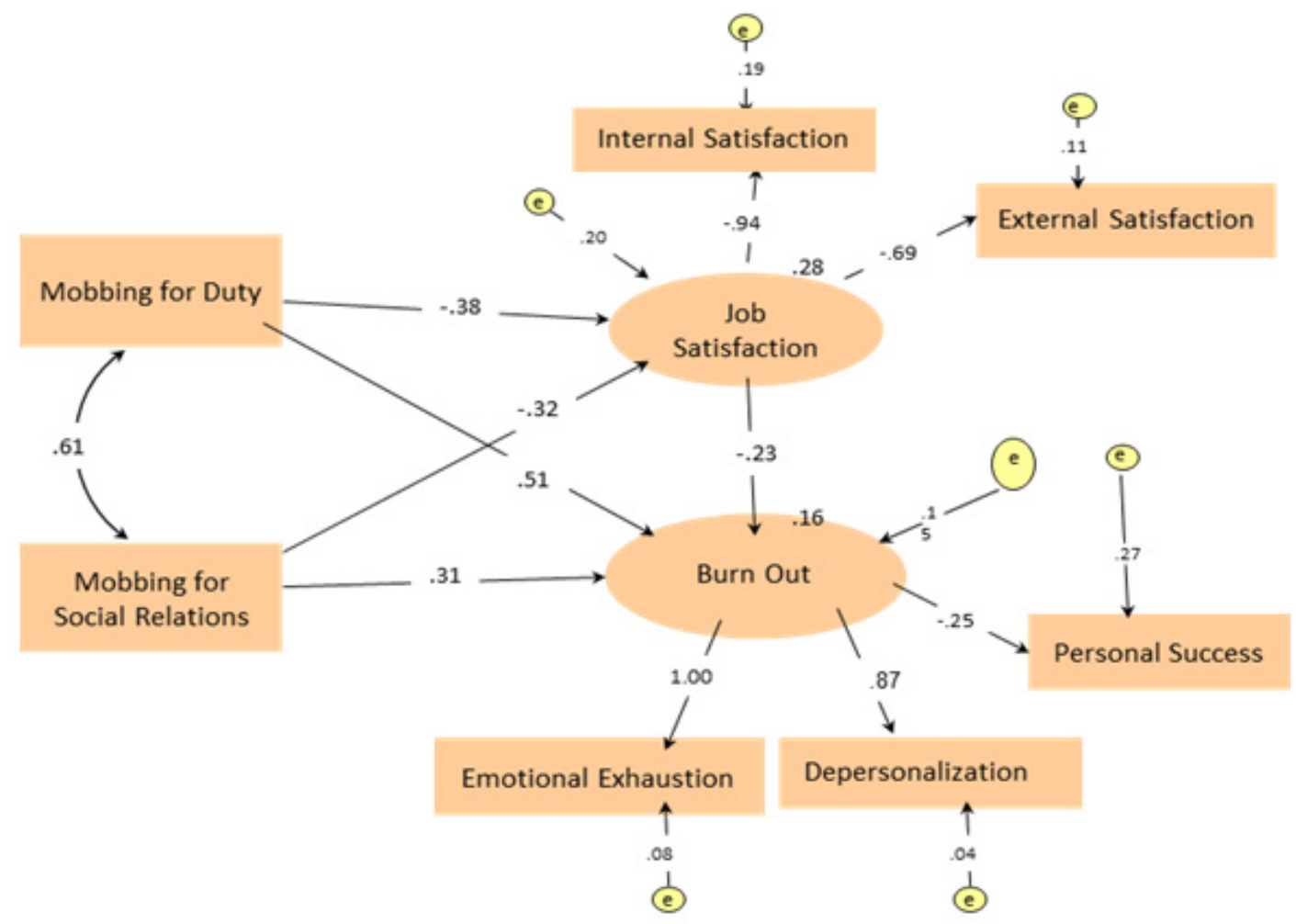

Figure 1. Results of standardised path analysis 
As seen in Table 2, on the basis of the perceptions of the primary and secondary school teachers, there is a negative and medium-level significant relationship between the exposure to work-related mobbing and mobbing directed at social relationships and their internal $(\mathrm{r}=-.39, \mathrm{p}<.01$; $\mathrm{r}=-.35, \mathrm{p}<.01)$ and external $(\mathrm{r}=-.31 ; \mathrm{p}<.01 ; \mathrm{r}=-.30$; $\mathrm{p}<.01)$ job satisfaction levels. Similarly, a positive and medium-level relationship was reported between the exposure to work-related mobbing and mobbing directed at social relationships among the primary and secondary school teachers and the emotional exhaustion $(\mathrm{r}=.52, \mathrm{p}<.01$; $\mathrm{r}=.41, \mathrm{p}<.01)$ and depersonalisation $(\mathrm{r}=.41, \mathrm{p}<.01$; $\mathrm{r}=.43, \mathrm{p}<.01)$ sub-dimensions of burnout. Moreover, a negative and low-level relationship was noted between the exposure to work-related mobbing and mobbing directed at social relationships among teachers and the personal accomplishment $(\mathrm{r}=-.17, \mathrm{p}<.01 ; \mathrm{r}=-.15, \mathrm{p}<.01)$ sub-dimension of burnout. The analysis carried out revealed a negative and low-level relationship between the internal and external job satisfaction levels of teachers and the emotional exhaustion $(\mathrm{r}=-.22, \mathrm{p}<.01 ; \mathrm{r}=-.24, \mathrm{p}<.01)$ and depersonalisation $(\mathrm{r}=-.21, \mathrm{p}<.01 ; \mathrm{r}=-.15, \mathrm{p}<.01)$ sub-dimensions of burnout. In addition, it was specified that there is a positive and low-level relationship between internal job satisfaction levels and the personal accomplishment $(\mathrm{r}=.24, \mathrm{p}<.01)$ sub-dimension of burnout while there is not a significant relationship between external job satisfaction levels and the personal accomplishment $(\mathrm{r}=.03, \mathrm{p}<.01)$ sub-dimension of burnout.

\subsection{How and to What Extent does the Exposure to Mobbing Behaviours among Primary and Secondary School Teachers Affect Their Job Satisfaction and Burnout Levels?}

Path analysis was carried out to determine how and to what extent does the exposure to mobbing behaviours towards primary and secondary school teachers affect their job satisfaction and burnout levels. Through path analysis, direct and indirect effects of predictor variables on predicted variables were determined. As a result of the analysis, some fit indices related to compliance of the model to data were examined. Most frequently used fit indices are $x^{2}$, GFI, AGFI, CFI, NFI, IFI, RMSEA and AIC. Among these fit indices, $x^{2}$ is sensitive to sample size and therefore, it is necessary to utilise $x^{2}$ together with other indicators. In terms of fit indices, certain criteria are applied, such as $x^{2} /$ sd value should be lower than 5, GFI should be higher than .90, IFI and CFI should be higher than .95 , and RMSEA should be lower than .06 [110], [111]. Moreover, if GFI, NFI, CFI and AGFI values, as fit indices are higher than .90 and RMSEA is lower than .05, this indicates that the model complies well with the data [112]. In this research, fit indices measured in relationship to the compliance of the model $(\mathrm{NFI}=.96$, $\mathrm{CFI}=.95, \mathrm{IFI}=.98, \mathrm{RMSEA}=.067, x^{2} / \mathrm{sd}=48 / 10=4.8<$ 5.00) show that the model complied well. Standardised path coefficients regarding how and to what extent does the exposure to mobbing behaviour among the primary and secondary school teachers affect their job satisfaction and burnout levels are given in Figure 1.

Figure 1 shows that when the standardised path coefficients are examined, work-related mobbing has slightly better indicators, in comparison with the mobbing directed at social relationships and that the internal job satisfaction dimension $(-.94)$ is the best indicator of job satisfaction. With regard to burnout, the emotional exhaustion dimension (1.00) is a stronger indicator than the depersonalisation dimension (.87). Work-related mobbing $(\beta=.51)$ is more effective on burnout, in comparison with job satisfaction $(\beta=-.23)$. This finding indicates that work-related mobbing is a stronger predictor for burnout than job satisfaction. A negative and medium-level relationship is observed between work-related mobbing and job satisfaction. Moreover, mobbing directed at social relationships $(\beta=.31)$ is more effective on burnout, as against job satisfaction $(\beta=-.23)$. This finding reveals that mobbing directed at social relationships is a stronger predictor for burnout than job satisfaction. However, work-related mobbing and mobbing directed at social relationships have a direct effect on burnout while work-related mobbing has an indirect significant effect through job satisfaction. In line with the increase in the exposure to work-related mobbing and mobbing directed at social relationships among the teachers, their job satisfaction levels decrease and thus their burnout levels increase. Nevertheless, the research showed that the effect of work-related mobbing $(\beta=-.38)$ and mobbing directed at social relationships $(\beta=-.32)$ on job satisfaction is negative and significant. Based on this finding, it may be deduced that the job satisfaction levels of the teachers may decrease upon their exposure to work-related mobbing and mobbing directed at social relationships. In other words, in line with the increase in the exposure to work-related mobbing and mobbing directed at social relationships among teachers, their job satisfaction levels decrease and burnout levels increase. When it is considered that the direct effect of job satisfaction on burnout is negative and significant $(\beta=-.23)$, it may be stated that the burnout perceptions of the teachers may be decrease in parallel to the increase in internal and external job satisfaction levels. Moreover, $28 \%$ of the total variance of the job satisfaction variable is explained on the basis of work-related mobbing and mobbing directed at social relationships. In addition, $16 \%$ of the total variance of the burnout variable is explained on the basis of work-related mobbing and mobbing directed at social relationships and a direct effect of the job satisfaction latent variable, as well as an indirect effect of work-related mobbing and mobbing directed at social relationships through the job satisfaction variable.

\section{Discussion}

As a result of the research, it has been determined that 
according to the perceptions of primary and secondary school teachers; teachers are exposed to unfavourable acts connected with the work-related mobbing dimension 'now and then'. This finding is in parallel with the findings of the research carried out by Cemaloğlu [113], Gündüz and Yılmaz [114], Einarsen and Rakness [40], Karyağdı [115], Kul [116], Kılınç [117], Okçu [118] and Onbaş [119]. When the studies concerning the frequency of the teachers' exposure to mobbing are examined under the related literature, it can be seen that different findings were obtained in these studies. Cemaloğlu [120], Hoel et al. [121], Hubert and Veldhoven [122], Dick and Wagner [41] and Toker [123] determined that the level of exposure to mobbing among the teachers is at medium level. Considering the replies of the teachers regarding the acts connected with the work-related mobbing dimension, it can be seen that the teachers are exposed to mobbing but their level of exposure is low.

As a result of the research, it has been determined that the perceptions of the primary and secondary school teachers regarding the mobbing directed at social relationships dimension is at the 'now and then' level. This result confirms the findings of the research carried out by Cemaloğlu [113], Cemaloğlu and Ertürk [8], Ertürk [124], Ergener [125], Gündüz and Yılmaz [114], Kılınç [117] and Onbaş [119], Sağlam [126] Toker [123] and Okçu [118]. Exposure to mobbing directed at the social relationships dimension among the teachers indicates that they are exposed to mobbing from top to bottom and horizontal mobbing, and that these two types of mobbing are more common in educational institutions. Intimidation of teachers by their colleagues in schools may be caused by the differences in the education understanding. Exposure to mobbing by the administrators or their colleagues has a negative effect on the climate in educational institutions. However, it is difficult to claim that teachers are exposed to mobbing systematically and intensely.

It has been determined that the internal job satisfaction levels of the teachers are at a good level while their external job satisfaction levels are at a medium level. It has also been specified that the worker with a high level of job satisfaction is healthier in comparison with the other workers and that they feel less stressed. Result of the research is remarkable in this regard. Many researches, especially those carried out after the 1980s, have revealed that the job satisfaction levels of the teachers are not at the required level [16], [18], [19], [20], [21], [22], [23], [24].

When the results concerning the burnout levels of the primary and secondary school teachers are examined, it has been found out that emotional exhaustion sub-dimension has the highest value while the depersonalisation has the lowest. The finding of this research is also supported by those obtained by Budakoğlu [127], Kepekçioğlu [128], Yıldız [129], Özgüner [50], Cerit [130] and Acar-Arasan [131]. Moreover, research on burnout, carried out by Koçak [64], Cemaloğlu and Erdemoğlu Şahin [26], Kayabaşı [132], Coşkun [133], Ergül, Saygın and Tösten [134], Torun [135],
Budak and Sürgevil [60], Avşaroğlu et al. [72], Tümkaya [136] reveal that teachers are exposed to mobbing. It is stated that emotional exhaustion found out to be high among primary and secondary school teachers may be caused by the problems in the triangle of school, student and parents; mostly by the inadequacies and disappointments related with the teaching profession. Moreover, it is also noted that excessive work load and stress may cause teachers to feel exhausted emotionally.

As a result of the research, it has been determined that there is a negative and medium-level relationship between the exposure to work-related mobbing and mobbing directed at social relationships among the teachers and their job satisfaction (internal and external) levels. Much research on the effect of mobbing at work on job satisfaction has been carried out both domestically and abroad [39], [87], [88], [89], [90], [91], [92] and has revealed that there is a negative relationship between mobbing and job satisfaction and that mobbing affects the psychological health of those exposed to it and decreases their job satisfaction. Şahin [137] stated that mobbing mostly affects the job satisfaction of the employee and their tendency to act unproductively.

A positive and medium-level relationship was reported between the exposure to work-related mobbing and mobbing directed at social relationships among the teachers and their burnout levels at the emotional exhaustion and depersonalisation sub-dimensions. Moreover, the relationship between the exposure to work-related mobbing and mobbing directed at social relationships among the teachers and their burnout levels at personal accomplishment sub-dimension is found to be negative and at a low level. In much research carried out both domestically and abroad [39], [94], [96], [97], [98] it has been determined that there is a positive relationship between the mobbing and burnout.

As a result of the analysis, a negative and low-level relationship was noted between the internal and external job satisfaction levels of the teachers and their burnout perceptions at emotional exhaustion and depersonalisation sub-dimensions. Moreover, it has been reported that there is a positive and low-level relationship between the internal job satisfaction levels of the teachers and their burnout levels at the personal accomplishment sub-dimension and that there is not a significant relationship between the external job satisfaction levels of the teachers and their burnout levels at the personal accomplishment sub-dimension. The research carried out by Koustelios and Tsigilis [99], Gençer [100], Bayram, Gürsakal and Bilgel [101] revealed a negative and significant relationship between the job satisfaction levels of the workers and their burnout levels, and thus it supports the results of this research.

\section{Conclusions}

According to the path analysis carried out under this research, in line with the increase in the exposure to work-related mobbing and mobbing directed at social 
relationships among the teachers, job satisfaction levels of the teachers decrease and, accordingly, their burnout levels increase. In other words, the job satisfaction levels of the teachers increase and correspondingly their burnout levels may decrease when the level of exposure to work-related mobbing and mobbing directed at social relationships among the teachers decreases. Moreover, it was also detected in the research that in line with the increase in external and internal job satisfaction levels of the teachers, their burnout perceptions may also diminish. In addition to this, it can be concluded that work-related mobbing and mobbing directed at social relationships are stronger predictors of burnout than job satisfaction.

In conclusion, mobbing negatively affects the human resources, quality and success by silently penetrating into schools, and has also a negative effect on the job satisfaction levels of the teachers and thus, increases their burnout levels. It may be ensured that teachers train in a healthy organisational climate by taking measures in this regard and applying sound policies accordingly. By this means, the learning success of the students may be enhanced and therefore, by making a contribution, the quality of education may also be improved. Based on the results of the study, the following suggestions may be made:

1) Research to establish the reasons for low job satisfaction levels and high burnout levels among the teachers may be carried out by utilising different methods (qualitative research).

2) More comprehensive research on the reasons of mobbing at schools may be carried out by utilising different methods (qualitative research).

3) Similar research may be carried out in the secondary schools and higher education institutions in different provinces and regions.

\section{REFERENCES}

[1] H. Leymann. The Content and Development of Mobbing At Work, European Journal of Work and Organizational Psychology, 5(2): 165-184, 1996.

[2] A.G. Toker. Mobbing: İş Yerinde Yıldırma Nedenleri ve Başa Çıkma Yöntemleri, (1. Bask1), Ankara: Pegem Akademi Yayıncılık, 2008.

[3] E. Işı1k. İşletmelerde Mobbing Uygulamaları ile İș Stresi İlişkisine Yönelik Bir Araştırma, Master Thesis, Yıldız Teknik Üniversitesi University, Institute of Social Sciences. İstanbul, 2007.

[4] S. Tayyar. İşletmelerde Psikolojik Yıldırma (Mobbing) ve Etkilerine Yönelik Bir Araștırma, Yayımlanmamış Yüksek Lisans Tezi, Gebze Yüksek Teknoloji Üniversitesi Sosyal Bilimler Enstitüsü, Kocaeli, 2008.

[5] Ç. Kırel. Örgütlerde Psikolojik Taciz ve Yönetimi, Eskişehir: Anadolu Üniversitesi İktisadi ve İdari Bilimler Fakültesi Yayınları, 2008.
[6] M. Kocaoğlu. Mobbing (İş Yerinde Psikolojik Taciz, Yıldırma) Uygulamaları ve Motivasyon Arasındaki İlişkinin İncelenmesine Yönelik Bir Araştırma, Master Thesis, Yıldız Teknik Üniversitesi University, Institute of Social Sciences. İstanbul, 2007.

[7] S. Tetik. Mobbing Kavramı: Birey ve Örgütler Açısından Önemi, KMÜ Sosyal ve Ekonomik Araştırmalar Dergisi, 12(18): 81-89, 2010.

[8] N. Cemaloğlu, A. Ertürk. Öğretmen ve Okul Müdürlerinin Maruz Kaldıkları Yıldırmanın Yönü, Bilig Dergisi, 46: 67-86, 2007.

[9] C. Maslach, S.E. Jackson. The Measurement of Experienced Burnout, Journal of Occupational Behavior, 2: 99-113, 1981.

[10] K.A. Özipek. Ortaöğretim Okullarında Görev Yapan Öğretmenlerde Mesleki Tükenmişlik Düzeyleri ve Nedenleri, Master Thesis, Trakya University, Institute of Social Sciences, Edirne, 2006.

[11] C. Maslach, W.B. Schaufeli, M.P. Leither. Job Burnout, Annual Review, Psychology, 52: 397-422, 2001.

[12] H. Izgar. Okul Yöneticilerinde İş Doyumu ve Örgütsel Bağlılık, Ahmet Keleşoğlu Eğitim Fakültesi Dergisi, 25: 317-334, 2008.

[13] R. Arı. Resmi Eğitim Kurumlarında Çalışan Psikolojik Danışma ve Rehberlik Uzmanlarının İş Doyumu ve Tükenmişlik Düzeylerinin Danışmanların Denetim Odağı ve Bazı Değişkenlere Göre Karşılaştırılması, Master Thesis, Selçuk University Institute of Social Sciences, Konya, 1999.

[14] E.A. Locke. The Nature and Causes of Job Satisfaction, Handbook of Industrial And Organizational Psychology, Chicago: Rand-Mcnally, 1976.

[15] E. Efeoğlu, H. Özgen. Hastane Çalışanlarında İş-Aile Yaşam Çatışması, İş Stresi ve Algılanan Sosyal Destek Arasındaki İlişkilerin Araştırılması, Çukurova Üniversitesi Sosyal Bilimler Enstitüsü Dergisi, 16(2): 237-254, 2007.

[16] A. Balcı. Eğitim Yöneticisinin İş Doyumu. Doctoral Dissertation, Ankara University, Institute of Social Sciences, Ankara, 1985.

[17] E. Örücü, S. Yumuşak, Y. Bozkır. Kalite Yönetimi Çerçevesinde Bankalarda Çalışan Personelin İş Tatmini ve İş Tatminini Etkileyen Faktörlerin İncelenmesine Yönelik Bir Araștırma, Celal Bayar Üniversitesi İktisadi ve İdari Bilimler Fakültesi Yönetim ve Ekonomi Dergisi, 13(1): 39-51, 2006.

[18] M.A. Birlik. Öğretmenlerin Mesleki Doyumu ve Eğitim Anlayışları, Master Thesis, Ege University, Institute of Social Sciences, İzmir, 1999.

[19] V. Çelik. Teknik Öğretmenlerin İș Doyumsuzluğu ve Ögrretmenlikten Ayrılmalarına Etkisi. Master Thesis, Ankara University, Institute of Social Sciences, Ankara, 1987.

[20] Ç. Demir. Ortaöğretim Kurumlarında Görev Yapan Rehber Öğretmenlerin İș Doyumu. Master Thesis, Ankara University, Institute of Social Sciences, Ankara, 1998.

[21] C. Çetinkanat. Örgütlerde Güdülenme ve İş Doyumu. Ankara: Anı Yayıncilik, 2000.

[22] J. Minibaş. Özel ve Devlet Okullarında Görev Yapan Öğretmenlerin İş Tatminin Düzeyi ve $\mathrm{Bu}$ Düzeyin Frustrasyon Karşısında Gösterilen Tepki ve Agresyon Yönü İle İlişkisi, Master Thesis, İstanbul University, Institute of Education Sciences. İstanbul, 1990. 
[23] N. Özdayı. Resmi ve Özel Liselerde Çalışan Öğretmenlerin İş Tatmini ve İs Streslerinin Karșılaștırılmalı Analizi, Doctoral Dissertation, İstanbul University, Institute of Social Sciences, İstanbul, 1990.

[24] A.C. Paknadel. Örgütsel İklim ve İş Doyumu. Doctoral Dissertation, Hacettepe University, Institute of Social Sciences, Ankara, 1988.

[25] G. Akçamete, S. Kaner, B. Sucuoğlu, B. Tükenmişlik İş Doyumu ve Kişilik, Ankara: Nobel Yayınları, 2001.

[26] N. Cemaloğlu, D.E. Şahin. Öğretmenlerin Mesleki Tükenmişlik Düzeylerinin Farkl1 Değişkenlere Göre İncelenmesi, Kastamonu Eğitim Dergisi, 15(2): 465-484, 2007.

[27] G. Girgin. İlkokul Öğretmenlerinde Meslekte Tükenmișliğin Gelişimini Etkileyen Değişkenlerin Analizi ve Bir Model Önerisi, Doctoral Dissertation, Dokuz Eylül University, Institute of Social Sciences, İzmir, 1995.

[28] B. Gündüz. İlköğretim Öğretmenlerinde Tükenmişlik, Mersin Üniversitesi Eğitim Fakültesi Dergisi, 1(1): 152-166, 2005.

[29] B. Sucuoğlu, A.N. Kuloğlu. Özürlü Çocuklarla Çalıșan Öğretmenlerde Tükenmişliğin Değerlendirilmesi, Türk Psikoloji Dergisi, 10(36): 44-60, 1996.

[30] S. Seğmenli. Rehber Öğretmenlerin Tükenmişlik Düzeylerinin İncelenmesi, Master Thesis, Hacettepe University, Institute of Social Sciences, Ankara, 2011.

[31] D. Şahin. Öğretmenlerin Tükenmişlik Düzeyinin Farklı Değişkenler Açısından İncelenmesi, Master Thesis, Gazi University. Institute of Educational Sciences, Ankara, 2007.

[32] A. Atakl1. Öğretmenlerin Stres ve İş Memnuniyeti, Çağdaş Eğitim Dergisi, 24(256): 7-13, 1999.

[33] Y. Ekinci. İlköğretim Okulu Yöneticilerinin Sosyal Beceri Düzeylerine Göre Öğretmenlerin İș Doyumu ve İş Stresinin Karşılaştırılması, Master Thesis, Gaziantep University, Institute of Education Sciences, Gaziantep, 2006

[34] C. Ergin. Akademisyenlerde Tükenmişlik ve Çeşitli Stres Kaynaklarının İncelenmesi, Hacettepe Üniversitesi Edebiyat Fakültesi Dergisi, 12 (1-2): 37-50, 1995.

[35] N. Özdayı. Resmi ve Özel Liselerde Çalışan Öğretmenlerin İş Streslerinin Karşılaștırılması, Marmara Üniversitesi Atatürk Eğitim Fakültesi Eğitim Bilimleri Dergisi, 5: 113-128, 1993.

[36] M. Agervold, E.G. Mikkelsen. Relationships Between Bullying, Psychosocial Work Environmentand İndividual Stres Reactions, Journal of Work And Stress, 18(4): 336-351, 2004.

[37] M.S. Araujo, S.E. Mclntyre, T.M. Mclntyre. Bullying At Workplace: Prevalence, Individual and Organizational Consequences, 6.Th International Conference On Workplace Bullying-Sharing Our Knowledge, Abstracts, (pp. 202-205), Institut Sante Et Societe, Montreal-Canada, 4-6 June, 2010.

[38] K. Björkquist, K. Österman, M. Hjelt-Back. Aggression Among University Employees, Agressive Behavior, 20(3), 173-184, 1994.

[39] S. Einarsen, S.B. Matthiesen, A. Skogstad, A. Bullying, Burnout and Well Being Among Assistant Nurses, The Journal of Accupational Healty And Safety, 6(14): 563-568, 1998.
[40] S. Einarsen, B.I. Raknes. Harassment in The Workplace and The Victimization of Men, Violence and Victims, 12: 247-263, 1997.

[41] R. Dick, U. Wagner. Stres and Strain in Teaching: A Structural Equation Approach, British Journal of Educational Psychology, 71: 243-259, 2001.

[42] M. Jenkins, H. Winefield, A. Sarris. What's in A Name? Workplace Bullying: Perceptions of Organisational Justice and Outcome in Workplace Bullying Policies and Procedures, 6.Th International Conference On Workplace Bullying-Sharing Our Knowledge, Abstracts, (pp. 49-50). Institut Sante Et Societe, Montreal-Canada, 4-6 June 2010.

[43] E.G. Mikkelsen, S. Einarsen. Bullying İn Danish Work-Life: Prevalence and Health Correlates, European Journal of Work And Organisational Psychology. 10: 393-413, 2001.

[44] M.B. Nielsen, S.B. Matthiesen, J. Hetland, S. Einarsen. Workplace Bullying, Mental Health and Job-Satisfaction: Findings From A Longitudinal Study, 6.Th International Conference On Workplace Bullying -Sharing Our Knowledge, Abstracts, (Ss. 58-59). Institute Sante Et Societe, Montreal-Canada, 4-6 June 2010.

[45] M. Vartia. The Sources of Bullying-Psychological Work Environment and Organizational Climate, European Journal of Work and Organizational Psychology, 5 (2): 203-214, 1996.

[46] D. Zapf. Organizational, Work Group Related And Personal Cause of Mobbing /Bullying at Work, International Journal of Manpower, 20(1-2): 70-84, 1999.

[47] M. Korkmaz, N. Cemaloğlu. The Relationship Between Workplace Bullying And Features of Learning Organizations, 6.Th International Conference On Workplace Bullying-Sharing Our Knowledge, Abstracts, (Ss. 193-195). Institut Sante Et Societe, Montreal-Canada, 4-6 June, 2010.

[48] B. G. Aktaş. Exploring The Workplace Mobbing And It's Relationship Between The Concepts of Organizational Climate and Organizational Trust, Master Thesis, Yeditepe University, Institute of Social Sciences, İstanbul, 2009.

[49] O. Sürgevil. Çalışma Hayatında Tükenmişlik Sendromu, Tükenmişlikle Mücadele Teknikleri, Ankara: Nobel Yayınları, 2006.

[50] M. Özgüner. Örgüt Kültürü ve Tükenmişlik İlişkisi Üzerine Bir Araştırma: Bozok Üniversitesi Örneği, Master Thesis, Bozok University, Institute of Social Sciences, Yozgat, 2011.

[51] M.N. Browne, M.A. Smith. Mobbing in The Worplace: The Latest Illustration of Pervasive Individuailsm in American Law, Employee Rights and Employment Policy Journal, 12:131-161, 2008

[52] E.G. Mikkelsen, S. Einarsen. Basic Assumptions and Symptoms of Post-Traumatic Stress Among Victims of Bullying at Work, European Journal of Work and Organizational Psychology, 11: 87-111, 2002.

[53] A. Ertürk. Öğretmen ve Okul Yöneticilerinin Okul Ortamında Maruz Kaldıkları Yıldırma Eylemleri (Ankara İli İlköğretim Okulları Örneği), Master Thesis, Gazi University, Institute of Education Sciences, Ankara, 2005.

[54] S. Branch. Upwards Bullying: An Exploratory Study of Power, Dependency and The Work Environment for Australian 
Managers, Doctoral Dissertation, Griffith University, Brisbane, Australia, 2006.

[55] P. Tınaz. İşyerinde Psikolojik Taciz (Mobbing), 2. Baskı, İstanbul: Beta Yayınları, 2008.

[56] D. Zapf, C. Knorz, M. Kulla. On The Relationship Between Mobbing Factors and Job Content, Social Work Environment and Health Outcomes, European Journal of Work and Organizational Psychology, 5(2): 215-237, 1996.

[57] N. Davenport, R.D. Schwartz, G.P. Elliott. Mobbing İșyerinde Duygusal Taciz, (Önertoy, O. Çev.), İstanbul: Sistem Yayınc1lık, 2003.

[58] Ş. Çobanoğlu. Mobbing İşyerinde Duygusal Saldırı ve Mücadele Yöntemleri, İstanbul: Timaş Yayınları, 2005.

[59] H. Izgar. Okul Yöneticilerinde Tükenmişlik, Ankara: Nobel Yayın Dağıtım, 2003.

[60] G. Budak, O. Sürgevil. Tükenmişlik ve Tükenmişliği Etkileyen Örgütsel Faktörlerin Analizine İlişkin Akademik Personel Üzerinde Bir Uygulama, Dokuz Eylül Üniversitesi İktisadi ve İdari Bilimler Fakültesi Dergisi, 20(2): 95-108, 2005.

[61] G. Akçamete, S. Kaner, B. Sucuoğlu. Öğretmenlerde Tükenmişlik İş Doyumu ve Kişilik, Ankara: Nobel Yayın Dağıtım, 2001.

[62] G.S. Arı, E. Ç. Bal. Tükenmişlik Kavramı: Birey ve Örgütler Açısından Önemi, Yönetim ve Ekonomi Dergisi, 5(1), 2008.

[63] K. Ardıç, S. Polatçı. Tükenmişlik Sendromu Akademisyenler Üzerinde Bir Uygulama (Gazi Osmanpaşa Üniversitesi), Gazi Üniversitesi İktisadi ve İdari Bilimler Fakültesi Dergisi, 10 (2): 69-96, 2008.

[64] R. Koçak. Okul Yöneticilerinin Mesleki Tükenmişlik Düzeylerinin Bazı Değişkenler Açısından İncelenmesi, Fırat Üniversitesi Sosyal Bilimler Dergisi, 19(1): 65-83, 2009.

[65] U. Akın, E. Oğuz. Öğretmenlerin İşkoliklik ve Tükenmişlik Düzeylerinin İlişkisi ve Çeşitli Değişkenler Açısından İncelenmesi, Kuram ve Uygulamada Eğitim Yönetimi, 16(3): 309-327, 2010.

[66] M. Ay, S. Avșaroğlu. Muhasebe Çalışanlarının Mesleki Tükenmişlik, İş Doyumu ve Yaşam Doyumlarının İncelenmesi 1-Mesleki Tükenmişlik Düzeyleri, Uluslararası İnsan Bilimleri Dergisi, 7(1), 1170-1189, 2010.

[67] A.Ç. Sağlam. Akademik Personelin Sosyo-Demografik Özelliklerinin Tükenmişlik Düzeyleri ile İlișkisi, Mustafa Kemal Üniversitesi Sosyal Bilimler Enstitüsü Dergisi, 8(15): 407- 420, 2011.

[68] F. Çetin, H.N. Basım, O. Aydoğan. Örgütsel Bağlılığın Tükenmişlik ile İlişkisi: Öğretmenler Üzerine Bir Araştırma, Selçuk Üniversitesi Sosyal Enstitüsü Dergisi, 25: 61-70, 2011.

[69] F. Sezgin, A.Ç. Kılınç. İlköğretim Okulu Öğretmenlerinin Mesleki Tükenmişlik Düzeyleri ile Örgütsel Vatandaşlık Davranışları Arasındaki İlişki, Ahi Evran Üniversitesi Kırşehir Eğitim Fakültesi Dergisi, 13(3):103-127, 2012.

[70] B. Gündüz, B. Çapri, Z. Gökçakan. Mesleki Tükenmişlik, İşle Bütünleşme ve İş Doyumu Arasındaki İlişkilerin İncelenmesi, Eğitim Araștırmaları Dergisi, 3(1): 29-49, 2013.
[71] U. Çapulcuoğlu, B. Gündüz. Öğrenci Tükenmişliğini Yordamada Stresle Başa Çıkma, Sınav Kaygısı, Akademik Yetkinlik ve Anne-Baba Tutumlar, Eğitim Bilimleri Araştırmaları Dergisi, 3(1): 201-218, 2013.

[72] S. Avşaroğlu, E. Deniz, A. Kahraman, A. Teknik Öğretmenlerde Yaşam Doyumu ve Mesleki Tükenmişlik Düzeylerinin İncelenmesi, Kastamonu Eğitim Dergisi, 15(2): 115-130, 2005

[73] N. Kaçmaz. Tükenmişlik Sendromu. İstanbul Üniversitesi İstanbul Tip Fakültesi Dergisi, 68(1): 29-32, 2005.

[74] A.B. Dolunay. Genel Liseler ve Teknik-Ticaret-Meslek Liselerinde Görevli Öğretmenlerde Tükenmişlik Durumu Araştırması, Ankara Üniversitesi Tıp Fakültesi Mecmuası, 55(1): 51-62, 2002.

[75] F. Akça. Örgütsel Davranışta Seçme Konular. Örgütsel Tükenmişlik ve Stres, (Ed: Mahmut Özdevecioğlu, Himmet Karadal), Ankara: İlke Yayınları, 2008.

[76] C. Maslach. Job Burnout: New Directions in Research and Intervention, Current Directions in Psychological Science, 12(5): 189-192, 2003.

[77] V. Işıkhan. Çalışma Hayatında Stres ve Başa Çıkma Yolları, Ankara: Sandal Yayınları, 2004.

[78] H. Izgar. Okul Yöneticilerinin Tükenmișlik Düzeyleri, Nedenleri ve Bazı Etken Faktörlere Göre İncelenmesi (Orta Anadolu Örneği), Doctoral Dissertation, Selçuk University, Institute of Social Sciences, Konya, 2000.

[79] İ. Bakan, T. Büyükbeşe. Çalışanların İş Güvencesi ve Genel İş Davranışları İlişkisi: Bir Alan Çalışması, Erciyes Üniversitesi İktisadi ve İdari Bilimler Fakültesi Dergisi, 23, 2004.

[80] İ. Barutçugil. Stratejik İnsan Kaynakları Yönetimi, İstanbul: Kariyer Yayınc1lık, 2004.

[81] D. Lund. Organizational Culture and Job Satisfaction, Journal of Business and Industrial Marketing, 18(3), 2003.

[82] M.O. Özkaya, V. Yakın, T. Ekinci. Stres Düzeylerinin Çalışanların İş Doyumu Üzerine Etkisi, Celal Bayar Üniversitesi İktisadi ve İdari Bilimler Fakültesi Yönetim ve Ekonomi Dergisi, 15(1): 163-179, 2008.

[83] F. Sevimli, Ö.F. İșcan. Bireysel ve İs Ortamına Ait Etkenler Açısından İş Doyumu, Ege Akademik Bakış Dergisi, 5 (1-2): 55-64, 2005.

[84] O. Zaman. Ortaöğretim Kurumlarında Çalışan Alan Dışından Atanmış Rehber Öğretmenlerinin İş Doyumları ile Örgütsel Bağlılıkları Arasındaki İlişki (Ankara İli Örneği), Master Thesis, Gazi University. Institute of Educational Sciences, Ankara, 2006.

[85] M.E. Bilir. Öğretmen Algılarına Göre İlköğretim Okul Yöneticilerin Dönüşümcü Liderlik Özellikleriyle Öğretmenlerin İş Doyumu İlişkisinin İncelenmesi, Master Thesis, Selçuk University, Institute of Social Sciences, Konya, 2007.

[86] J. Voroney. Workplace Bulling: A Cultural Perspective, Culture of Peace Online Journal, 1(1):23, 2005.

[87] Z.J. Jelic, E. Stoini, S.C. Bunikic. The Effect of Mobbing on Medical Staff Performance, Acta Clin Croat, 4: 347-352, 2005. 
[88] M. Vartia. Workplace Bullying: A Study on The Work Environment, Well-Being and Health, Doctoral Dissertation, Institute of Occupational Health, Helsinki, 2003.

[89] A. Çivilidağ. Üniversitelerdeki Öğretim Elemanların Psikolojik Taciz (Mobbing), İs Doyumu ve Algılanan Sosyal Destek Düzeyleri, Doctoral Dissertation, Selçuk University, Institute of Education Sciences, Konya, 2011.

[90] M.A. Doğan. İlköğretim Okullarında Öğretmenlere Uygulanan Psikolojik Şiddetin (Mobbing) İş Doyumuna Etkisi, Ankara İli Sincan İlçesi Örneği, Master Thesis, Atılım University, Institute of Social Sciences, Ankara, 2009.

[91] H. Okan. Ortaöğretim Öğretmenlerinin Karşılaştıkları Yıldırıcı Davranışlar ile İş Doyumu Arasındaki İlişki, Master Thesis, Yeditepe University, Institute of Social Sciences, İstanbul, 2010.

[92] Ü.N. Dinçer. Hemşirelerin İşyeri Şiddetine Maruz Kalma Durumları ile İş Doyumları ve İşten Ayrılma Eğilimleri, Doctoral Dissertation, Hacettepe University, Institute of Healty Sciences, Ankara, 2010.

[93] S. Dursun. İşyeri Şiddetinin Çalışanların Tükenmişlik Düzeyi Üzerine Etkisi: Sağlık Sektöründe Bir Uygulama, Çalışma İlişkileri Dergisi, 3(1): 105-115, 2012.

[94] E. Alkan. Yıldırma (Mobbing) Davranışlarının Beden Eğitimi ve Spor Öğretmenlerinin Tükenmişliği Üzerine Etkisi, Master Thesis, Balıkesir University, Institute of Social Sciences, Balıkesir, 2011.

[95] M. Karakuş, İ.H. Çankaya. Öğretmenlerin Maruz Kaldıkları Psikolojik Şiddete İlişkin Bir Modelin Sınanması, Hacettepe Üniversitesi Eğitim Fakültesi Dergisi, 42: 225-237, 2012.

[96] B. Filizöz, A. F. Ay. Örgütlerde Mobbing ve Tükenmişlik Olgusu Arasındaki İlişkilere Yönelik Bir Araştırma, E-Journal Of New World Sciences Academy, 6(2), 2011.

[97] N.M. Bucaklar. Öğretmenlerin Maruz Kaldıkları Yıldırma Eylemlerinin Tükenmişlikleri ve Bazı Değişkenler ile İlişkisinin İncelenmesi, Master Thesis, Maltepe University, Institute of Social Sciences, İstanbul, 2007.

[98] L. M. Varhama, K. Björkqvist. Conflicts, Workplace Bullying and Burnout Problems Among Municipal Employees, Psychological Reports, 94: 1116-112, 2004.

[99] A. Koustelios, N. Tsigilis. The Relationship Between Burnout And Job Satisfaction Among Physical Education Teachers: A Multivariate Approach. European Physical Education Review, 11(2): 189-203, 2005.

[100]A. Gençer. Öğretmenlerin İş Doyumu ile Mesleki Tükenmişlik Düzeyleri Arasındaki İlişkiler, Master Thesis, Eskişehir Osmangazi University, Institute of Social Sciences, Eskişehir, 2002.

[101] N. Bayram, S. Gürsakal, N. Bilgel. Burnout, Vigor and Job Satisfaction Among Academic Staff, European Journal of Social Sciences, 17(1):41-53, 2010.

[102] D. Katz, R. L. Kahn. Örgütlerin Toplumsal Psikolojisi, Ankara: TODAİE Yayınları, 1977.

[103] F. Karcıoğlu, Ü. H. Çelik. Mobbing (Yıldırma) ve Örgütsel Bağl1lığa Etkisi, Atatürk Üniversitesi İktisadi ve İdari Bilimler Dergisi, 26 (1): 59-75, 2012.

[104] F. Karcioğlu, S. Akbaş. İşyerinde Psikolojik Şiddet ve İş
Tatmini İlişkisi, Atatürk Üniversitesi İktisadi ve İdari Bilimler Dergisi, 24 (3): 139-161, 2010.

[105]F. M. Durdağı, A. Naktiyok. Psikolojik Taciz Algısının Örgütsel Güven Üzerindeki Etkisi, Kafkas Üniversitesi İktisadi ve İdari Bilimler Dergisi, 1(2): 5-37, 2011.

[106] N. Karasar. Bilimsel Araştırma Yöntemi, Ankara: Nobel Yayınları, 2007.

[107] G. Girgin, A. Baysal. Zihinsel Engelli Öğrencilere Eğitim Veren Öğretmenlerin Mesleki Tükenmişlik Düzeyi ve Bazı Değișkenler (İzmir Örneği), Pamukkale Üniversitesi Eğitim Fakültesi Dergisi, 18, 2006.

[108] D.J. Weiss, R.V. Dawis, G.W. England, L.H. Lofquist. Manual For The Minnesota Satisfaction Questionnaire, Minnesota Studies in Vocational Rehabilitation, 22: 120 Minnesota: University of Minnesota, 1967.

[109] A. Baycan. Analysis of Several Aspects of Job Satisfaction Between Different Occupational Groups, Master Thesis, Bogaziçi University, Institute of Social Sciences, İstanbul, 1985.

[110]B. M. Byrne. Structural Equation Modeling With LISREL, PIRELIS and SIMPLIS: Basic Concepts, Applications and Programming, Hillsdale: Lawrens Erbaum Associates, 1998.

[111] K.G. Joreskog, D. Sörbom. LISREL 8 User's Reference Guide; PRELIS 2 User's Refrence Guide. Chicago: Scientific Software International, 1993.

[112] L.T. Hu, P.M. Bentler. Cut off Criteria For Fit Indexes in Covariances Structure Analysis: Conventional Criteria Versus New Alternatives, Structual Equation Modeling, 6, $1-55,1999$.

[113] N. Cemaloğlu. The Relationship Between Leadership Styles of Primary School Principals and Organizational Health of School and Workplace Bullying, Journal of Educational Administration, 49 (5): 1-37, 2011.

[114]H. B. Gündüz, O. Y1lmaz. Ortaöğretim Kurumlarında Mobbing Davranışlarına İlişkin Öğretmen ve Yönetici Görüşleri (Düzce İli Örneği), Milli Eğitim Dergisi, 37 (179): 269-282, 2008

[115] A. Karyağdı. Örgütlerde Yıldırma (Mobbing) ve Bir Araştırma, Master Thesis, İnönü University, Institute of Social Sciences, Malatya, 2007.

[116] M. Kul. Okul Yöneticilerinin Liderlik Stilleri ile Beden Eğitimi Öğretmenlerinin Yıldırma (Mobbing) Yaşama Düzeyleri, Örgütsel Bağll1ıkları ve İs Doyumu Arasındaki İlişki, Doctoral Dissertation, Gazi University, Institute of Education Sciences, Ankara, 2010.

[117] A. C. Kılınç. Okul Yöneticilerinin Etik Liderlik Davranışları Gösterme Düzeyleri ile Öğretmenlerin Yaşadıkları Örgütsel Güven ve Yıldırma Arasındaki İlişki, Master Thesis, Gazi University, Institute of Education Sciences, Ankara, 2009.

[118] V. Okçu. Okul Yöneticilerinin Liderlik Stilleri ile Öğretmenlerin Örgütsel Bağlılıkları ve Yıldırma Yaşama Düzeyleri Arasındaki İlişkilerin İncelenmesi, Doctoral Dissertation, Gazi University, Institute of Education Sciences, Ankara, 2011.

[119] N. Onbaş. İlköğretim Okulu Öğretmenlerinin Eğitim Örgütlerinde Duygusal Şiddete İlişkin Görüşleri Üzerine Bir Araştırma, Master Thesis, Harran University, Institute of Social Sciences, Şanlıurfa, 2007. 
[120] N. Cemaloğlu. Okul Yöneticilerinin Liderlik Stilleri ile Yıldırma Arasındaki İlişki. Hacettepe Üniversitesi Eğitim Fakültesi Dergisi, 33: 77-87, 2007.

[121] H. Hoel, B. Faragher, C. Cooper. Bullying is Detrimental To Health, But All Bullying Behaviours Are Not Necessarily Equally Damaging, British Journal of Guidance and Councelling, 32(3), 367-387, 2004.

[122] A. Hubert, M. Veldhoven. Risk Sectors For Undesirable Behaviour and Mobbing, European Journal of Work and Organizational Psychology, 10 (4), 2001.

[123] G. A. Toker. İşyerinde Yıldırma: Özel ve Resmi İlköğretim Okulu Öğretmen ve Yöneticileri Üzerine Yapılan Bir Araştırma, Doctoral Dissertation, Ankara University, Institute of Education Sciences, Ankara, 2006.

[124] A. Ertürk. İlköğretim Okullarında Görevli Öğretmen ve Yöneticilere Yönelik Duygusal Yıldırma Davranışlarının İncelenmesi, Doctoral Dissertation, Gazi University, Institute of Education Sciences, Ankara, 2011.

[125] B. Ergener. İlköğretim Okullarında Görev Yapan Öğretmenlerin Yıldırma Yaşamaları ile Örgütsel Bağlılıkları Arasındaki İlişki (İstanbul İli Örneği), Master Thesis, Gazi University, Institute of Education Sciences, Ankara, 2008.

[126] Ç.A Sağlam. İlköğretim Okullarında Mobbing'e (Psikolojik Şiddete) İlişkin Öğretmen Görüşleri, Eğitim Araştırmaları Dergisi, 32: 133-142, 2008.

[127] G. Budakoğlu. Tükenmişliğin Örgütsel Bağlılığa Etkisi: Bir Devlet Üniversitesi Öğrencileri Üzerinde Bir Araştırma, Master Thesis, Sakarya University, Institute of Social Sciences, Sakarya, 2011.

[128]E.S. Kepekçioğlu. Öğretim Elemanlarında Tükenmişlik. Master Thesis, Abant İzzet Baysal University, Institute of Social Sciences, Bolu, 2009.

[129] E. Yıldız. Eğitimcilerde Tükenmișlik (Rehber Öğretmenler
Üzerinde Bir Araştırma), Master Thesis, Sakarya University, Institute of Social Sciences, Sakarya, 2011.

[130] Y. Cerit. İlköğretim Okulu Müdürlerinin Hizmet Yönelimli Liderlik Davranışlarının Öğretmenlerin Tükenmişliklerine Etkisi, Kuram ve Uygulamada Eğitim Yönetimi, 55: 547-570, 2008.

[131] B.N.A. Arasan. Akademisyenlerde Yaşam Doyumu, İş Doyumu ve Mesleki Tükenmişlik Düzeylerinin Belirlenmesine Yönelik Bir Araştırma, Master Thesis, Uşak University, Institute of Social Sciences, Uşak, 2010.

[132] Y. Kayabaşı. Bazı Değişkenler Açısından Öğretmenlerin Mesleki Tükenmişlik Düzeyleri. Gazi Üniversitesi Sosyal Bilimler Dergisi, 20, 191-212, 2008.

[133] M.K. Coşkun. Din Kültürü ve Ahlak Bilgisi Öğretmenlerinin Tükenmişlik Düzeylerinin Çeşitli Değişkenlere Göre İncelenmesi, Elektronik Sosyal Bilimler Dergisi, 41: 101-113, 2012.

[134] H.F. Ergül, S. Saygın, R. Tösten. Sınıf Öğretmenlerinin Tükenmişlik Düzeylerinin Çeşitli Değişkenler Açısından İncelenmesi, Dicle Üniversitesi Sosyal Bilimler Enstitüsü Dergisi, 5 (10): 266-285, 2013.

[135]A.A. Torun. Tükenmişlik, Aile Yapısı ve Sosyal Destek İlişkileri Üzerine Bir İnceleme. Doctoral Dissertation, Marmara University, Institute of Social Sciences, İstanbul, 1995.

[136] S. Tümkaya. Öğretmenlerin Sınıf İçi Disiplin Anlayıșları ve Tükenmişlikle İlişkisi, Kuram ve Uygulamada Eğitim Yönetimi, 44: 549-568, 2005.

[137] N. Şahin. Duygusal Taciz (Mobbing) ve Organizasyonel Sonuçlar Üzerindeki Etkisi: Bankacılık Sektöründe Bir Uygulama, Master Thesis, İstanbul University, Institute of Social Sciences, İstanbul, 2006.

\footnotetext{
iThis study was supported by Siirt University Scientific Research Project Coordination Unit (BAP) during the 2014-2015 school year. An oral presentation about this study was given at the ' $11^{\text {st }}$ International Conference on Lifelong Education and Leadership for ALL-ICLEL 2015 ' organized by Palacky University \& Moravian University College Olomouc, Czech Republic, October 29-31, 2015.
} 